\title{
EFFECTIVENESS OF LOTION EXTRACT OF VARIOUS TYPE OF PLANTS AS Aedes aegypti MOSQUITO REPPELENT
}

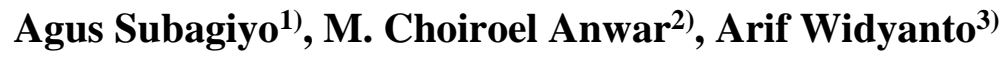 \\ ${ }^{122) 3)}$ Department of Environmental Health \\ Health Polytechnic of the Ministry of Health, Semarang, Indonesia
}

\begin{abstract}
Effort to control DHF (Dengue Hemorrhagic Fever) vectors without toxic substances by using natural and enviromentally friendly materials was natural repellent made using plants that were widely available in the community.Many types of plants contain various secondary metabolite compound substances that have the potential to be used as natural insecticides, especially as repellent of the Aedes Aegypti mosquito. The research needs to be done to determine the effectiveness of basil leaves, citronella leaves, clove leaves and betel leaves as a repellent against Aedes Aegypti mosquitoes. This research method was an experiment in the laboratory. The materials used for this research were basil leaves, citronella leaves, clove leaves, and betel leaves. The extracted leaves were then made lotions with certain formulas, tested as a natural repellent against Aedes Aegypti mosquitoes. The concentrations used were $20 \%, 40 \%$ and $80 \%$ as well as negative control (0\%) and positive control (brand $\mathrm{x}$ lotions). The number of mosquitoes used in the study were $25 \mathrm{x} 4$ treatments $=100$ mosquitoes. The replication or repetition was done 10 times. To find out the difference in the number of Aedes Aegypti mosquitoes that perch on the hands of probandus which has been smeared with basil leaf, citronella leaf, clove leaf and betel leaf extracts uses Anova Statistical tests and kruskal wallis. To see the difference between concentrations was tested with LSD or Mann-Whitney test. The calculation result of the number of Aedes Aegypti mosquitoes that perch before and after applying the lotion, the lowest was the lotion of citronella leaf extract $0 \%$ (11); $20 \%$ (2); $40 \%$ (1); $80 \%$ (1); The highest protection capacity of extract lotion is citronella leaves with concetrations of $20 \%(81,1 \%) ; 40 \%(95 \%)$, $80 \%(98,2 \%)$; There were no significant differences between the lotion concentrations of $20 \%$ and $80 \%$, while the concentration of $40 \%$ is significantly different. Then the LSD follow-up test finds that the protective capacity of lotion of clove leaf extract is negative and citronella leaf extract is positive. The most effective protection capacity against Aedes Aegypti mosquitoes was lotion of citronella leaf extract with concentration of $40 \%$ (95\%) and a concentration of $80 \%(98,2 \%)$, proven by the value of protection capacity that is stable even though it has been used for up to 6 hours and can exceed the protection capacity of lotion $\mathrm{x}(90,3 \%)$. It is reccomended that further research needs to be developed to optimize the lotion of citronella leaf extract $40 \%$ and $80 \%$ with orgonolaptic test of color, aroma, stickness and comfort of its use.
\end{abstract}

Keywords : basil leaf, citronella leaf, betel leaf, and clove leaf extracts; and Aedes aegypti

\section{Introduction}

The use of mosquito repellent in the form of lotions, creams that could protect the body from mosquito bites could actually harm health. The use of mosquito repellent in the form of lotions, creams, or the like that could protect the body from mosquito bites could actually harm health because almost all mosquito repellent lotions circulating in Indonesia were made from active DEET (Diethyl toluamide) that was a toxic synthetic chemical. According to the case, alternative dengue fever vector control efforts used natural and environmentally friendly materials made using plants that were widely found in the community.

The natural and environmentally friendly ingredients were repellent in the natural lotions form of Basil leaves, Citronella fragrance, clove leaves and betel leaves that have content such as sitronelal, geraniol, methylheptenon, terpenalkohol, which could used as a repellent Aedes aegypti. Based on the description above, it was necessary to know the effectiveness of natural lation-shaped repellent Basil, Serei fragrance, clove leaves, betel leaves as 
repellent-shaped lotion against Aedes aegypti mosquitoes.

\section{Material and Method}

The type of the research was an experiment in the laboratory. The materials that used for the research were basil leaves, citronella, clove leaves and betel leaves. The plant was extracted then made lotion formula continues to be tested as a natural repellent against the Aedes aegypti mosquito. The concentrations that used $20 \%, 40 \%$ and $80 \%$ and controls $(0 \%)$. The number of mosquitoes used in the study was $25 \times 4$ treatments $=100$ mosquitoes. The replication or replay was performed in 10 times. To find out the difference using the stastistic test kruskal walis. To see the difference between concentrations tested with LSD or Mann-Whitney tests.

\section{Result and Discussion}

\section{a. Results}

The results of air temperature measurement at the beginning of contact time and observation 6 hours after testing at the research's place $25,5^{\circ} \mathrm{C}-26,5^{\circ} \mathrm{C}$ Results of moisture measurement at the beginning of contact time and observation 6 hours after testing at the research's place : $72 \%-73 \%$

Before smearing the repelent, the probandus hands were washed with clean water and dried first. During repelent testing, probandus hands should not be cleaned or touched other objects until the completion of lotion testing activities as repelent (about 6 hours from 08.00 a.m until 02.00 p.m). The mosquito that used for the study was the female Aedes aegypti mosquito. The Aedes aegypti mosquito used is a mosquito hatched from eggs through rearing activities at the P2B2 Ciamis Hole in Pangandaran. The age of mosquitoes that has been used was 2-3 days. Mosquito cages used in this study used cages made of nylon gauze that amounted to 4 pieces of mosquito cage, with a mosquito cage size of $35 \times 35 \times 35 \mathrm{~cm}^{3}$. Every mosquitos' cage were filled with 25 test mosquitoes.

The average of mosquitoes that reach on the hands of probandus as much as 1 mosquito with a standard deviation of 0.841 . The test results of different kruskal wallis processed cisquare value: 14,562 and $\mathrm{P}$ value $<0.002$ means there was a difference in the number of mosquitoes that were up to each concentrations of basil leaf extract lotion.

Average mosquitoes that reach the hands of probandus as much as 1 mosquito with a standard deviation of 0.7116. Because the data was not distributed normally, then the test was different using non parametric that was kruskal wallis processed Cisquare value: 17,220 and $\mathrm{P}$ value $<0.001$ means there was a difference in the number of mosquitoes that were up to each concentration of lotion citronella extract.

The average of mosquitoes that reach on the hands of probandus as much as 1 mosquito with a standard deviation of 0.947 . Because the data was distributed normally then using a different test oneway anova, the result was processed value $\mathrm{F}$ : 22.189 and $\mathrm{P}$ value $<0.000$ means there was a difference in the number of mosquitoes that were up to each concentration of clove extract.

Average mosquitoes that reach on the hands of probandus as much as 1 mosquito with a standard deviation of 0.9632 . Because the data was distributed normally then using a different test oneway anova, the result was processed value F: 50.854 and $\mathrm{P}$ value < 0.000 means there was a difference in the number of mosquitoes that were up to each concentrations of betel extract.

Protection power Extract Against Mosquitoes Aedes aegypti on the hands of probandus after smeared basil leaf extract lotion, citronella, clove leaves and betel leaves with a concentration of $20 \%$, nothing could exceed the protection power of lotion $\mathrm{X}$, it could be concluded that there was nothing most effective of the four lotion extracts.

Protection power Extract Against Mosquitoes Aedes aegypti on the hands of probandus after smeared basil leaf extract lotion, citronella, clove leaves and betel leaves with a concentration of $40 \%$, it could be concluded that the most effective was a scented citronella extract lotion, evidenced from a stable protection power value even though it has been used for up to 6 hours.

Protection Power Extract Against Mosquitoes Aedes aegypti on probandus hands after smeared basil leaf extract lotion, citronella, clove leaves and betel leaves with a concentration of $80 \%$ at the 1 st hour to the 6 th hour.

Protection power Extract Against Mosquitoes Aedes aegypti on the hands of probandus after smeared basil leaf extract lotion, Citronella leaves, clove leaves and betel leaves with a concentration of $80 \%$, could be concluded that the most effective was still lotion citronella extract both $40 \%$ and $80 \%$, has a higher protection power than lotion $\mathrm{X}$, evidenced by a stable protection value even though it has been used for up to 6 hours.

The Differences Between Lotion Extract Protection Power

The difference in the protective power of the lotion extracts of basil leaves, citronella leaves, clove leaves, and betel leaves at a concentration of $20 \%$ and $80 \%$ of the protective power was not significantly different, while at a concentration of $40 \%$ it was significantly different. Then the LSD continued test 
found that the most different protective power was the negative value of the clove leaf extract lotion, meaning that it was the smallest compared to the protection power of other extract lotions. Meanwhile, citronella leaf extract lotion is positive.

1) The Effectiveness of Protection Power

Effectiveness of protection power against $\mathrm{Ae}$ mosquitoes. Aegypti from clove leaf extract, betel leaf extract and citronella extract at the 1 st to 6 th hour with a concentration of $20 \% ; 40 \% ; 80 \%$ as below chart:

Graph 4.1 Effectiveness of protection power various extract at 1st hour to 6th hour concentration $20 \%$.

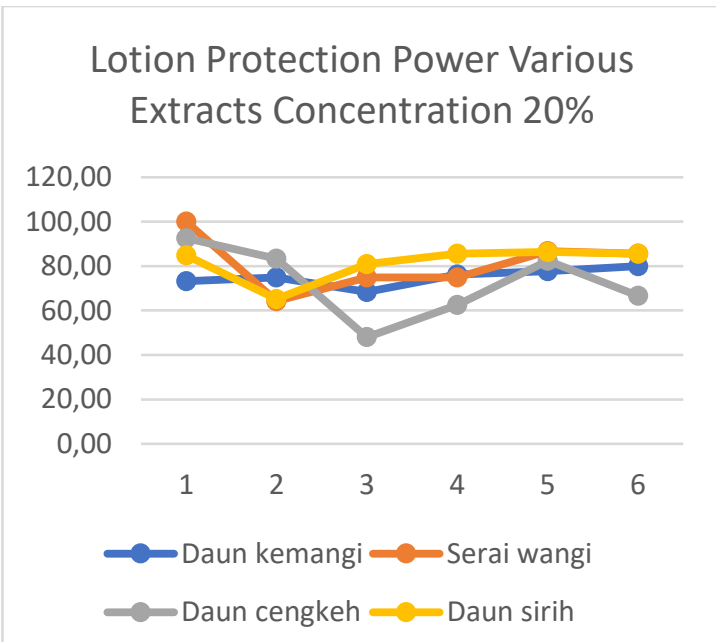

Based on the chart above, it can be concluded that there is no most effective of the four lotion extracts.

Graph 4.2 Effectiveness of protection power from various extract at 1 st hour to 6th hour $40 \%$ concentration

\section{Daya Proteksi Lotion Berbagai \\ Ekstrak Konsentrasi 40\%}

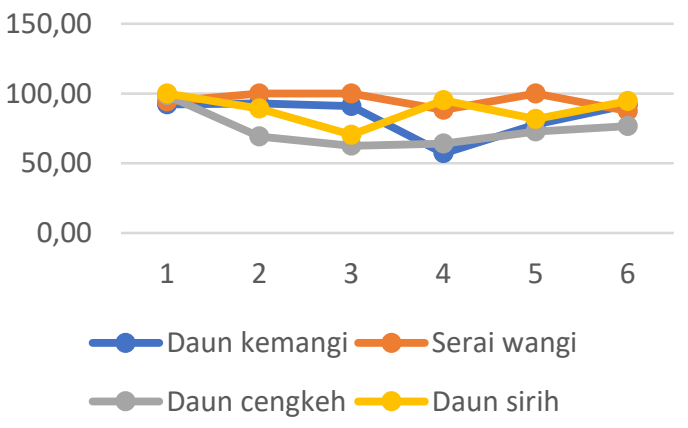

Based on the paragraph above the concentration of $40 \%$, it can be concluded that the most effective is citronella, as evidenced by the value of the protective power which is stable even though it has been used for up to 6 hours.
Graph 4.3 The effectiveness of protection against mosquitoes Ae. Aegypti from various extract at the 1 st to 6th hour with a concentration of $80 \%$.

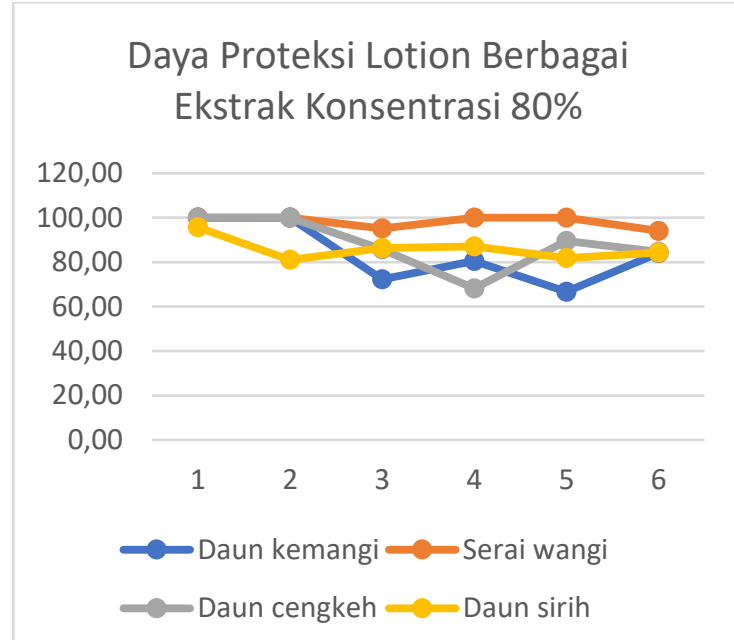

Based on graph 4.3 above a concentration of $80 \%$, it can be concluded that the most effective is citronella extract, as evidenced by the value of the protective power which is stable even though it has been used for up to 6 hours.

2) Analyzing the ratio of protection against A. aegyptid mosquitoes from various extract at a concentration of $20 \%, 40 \%$, $80 \%$. with positive control lotion X.

Graph 4.4. Protection Power Lotion Various Extracts $20 \%$ Concentration

\section{Daya Proteksi Lotion Berbagai Ekstrak Konsentrasi 20\%}

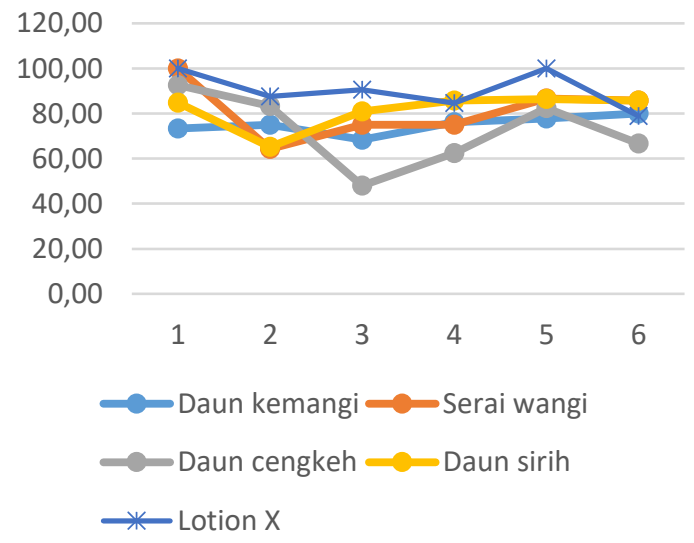

Protection power of various lotions with $20 \%$ concentration, none of which can exceed the protective power of lotion $\mathrm{X}$, the highest protection power at a concentration of $20 \%$ is betel leaf extract lotion $(81.5 \%)$. Lotion $\mathrm{x}$ has a protective power (90.3\%). 
Graph 4.5. Protection Power of Lotion Various Extracts Concentration $40 \%$

\section{Daya Proteksi Lotion Berbagai Ekstrak Konsentrasi 40\%}

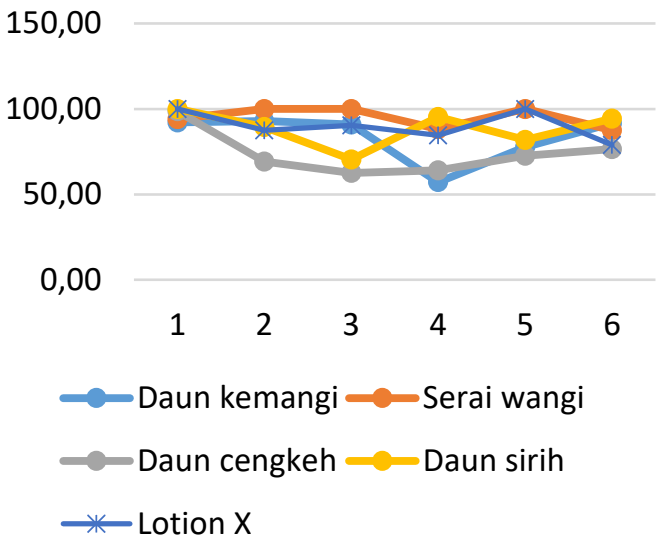

Based on graph 4.5 above, it can be concluded that citronella with a concentration of $40 \%$ has a protective power (average $95 \%$ ) which can exceed the protective power of lotion X. (average 90.3).

Graph 4.6. Protection Power of Lotion Various Extracts Concentration $80 \%$

\section{Daya Proteksi Lotion Berbagai Ekstrak Konsentrasi 80\%}

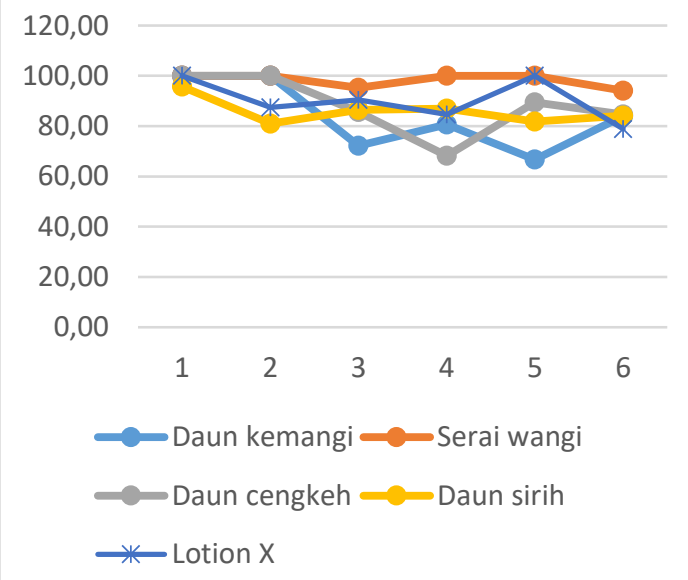

Based on the graph above, it can be concluded that $80 \%$ citronella has a protective power $(98.2 \%)$ which can exceed the protective power of lotion X.The most effective lotion is the citronella extract lotion with a concentration of $20 \%$ (81.1\%), 40\%. (95\%), 80\% $(98.2 \%)$ and it is proven from the value of the protective power which is stable even though it has been used for up to 6 hours.

b. Discussion

1) State of Physical Environment

According to Sucipto, 2011, the temperature and humidity in which mosquitoes live will indirectly affect the Aedes aegypti mosquito population. At temperatures above $35^{\circ} \mathrm{C}$ it affects the physiological processes of mosquitoes. While the optimum temperature for mosquito growth is between $25^{\circ} \mathrm{C}$ $27^{\circ}$ C. Mosquito growth will completely stop at temperatures less than $10^{\circ} \mathrm{C}$ or more than $40^{\circ} \mathrm{C}$. Meanwhile, the larva growth process requires temperatures between $25 \circ{ }^{\circ}$ C-30 ${ }^{\circ}$ C. https://inspeksisanitasi.blogspot.co.id/2012/10/epide miologi-demam-berdarah.html. In general, the measured air temperature factor has no effect on the behavior and activity of the tested Aedes Aegypti mosquito.

The optimal humidity required for mosquito growth is between $60 \%$ and $80 \%$. If the conditions of air temperature and humidity are optimal, the age of the mosquitoes can reach one month (average age of female Aedes aegypti mosquitoes is 10 days). The humidity factor indirectly affects the age of the mosquitoes. high humidity causes mosquitoes to quickly become lousy so that it can cause death. Whereas at humidity less than $60 \%$ the mosquito lifespan will be short. https://inspeksisanitasi. blogspot.co.id/2012/10/epidemiologi-demamberdarah.html.

Based on the results of measurements of the physical environment including temperature and humidity, it can be concluded that these conditions are optimal conditions to support the activity of the Aedes Aegypti mosquitoes. The results of these physical environmental measurements did not affect the Aedes Aegypti mosquito activity to find prey in maintaining its life span.

2) Result of Analysis

The mosquitoes that land on the hands of probandus on the lotion of basil leaf extract and citronella because the data are not normally distributed, the statistical test using the Kruskal Wallis difference test results in a CiSquare value: 14.562 and a $\mathrm{p}$ value $<0.002$, meaning that there is a difference in the number of mosquitoes that perch at each lotion concentration. Basil extract while citronella extract lotion obtained CiSquare value: 17.220 and $p$ value $<0.001$, which means that there is a difference in the number of mosquitoes that land on each concentration of citronella extract lotion.

Mosquitoes perched on probandus hands on clove leaf extract lotion and betel leaf because the data were normally distributed, the statistical test used the Oneway ANOVA test, the results obtained were $F$ value: 22,189 and $p$ value $<0,000$ means that there was a difference in the number of mosquitoes that perched on each extract concentration. clove. Meanwhile, the betel extract lotion obtained $\mathrm{F}$ value: 50.854 and $p$ value $<0.000$, which means that there is 
a difference in the number of mosquitoes that land on each betel extract concentration.

a) Lotion Protection Power Extract various plants

The protection power of extract lotion against Aedes aegypti mosquitoes on probandus hands after being smeared with lotion extracts of basil leaves, citronella, clove leaves and betel leaves with a concentration of $20 \%$ in the 1 st to 6 th hours, the betel leaf extract lotion has the highest protection power ( $81.5 \%$ ) while citronella extract lotion had the second protective power $(81.1 \%)$. nothing can exceed the protective power of lotion X $(90.3 \%)$, it can be concluded that none of the four lotions of natural ingredients extract with a concentration of $20 \%$ is the most effective.

Protection Power of Lotion Extract against Aedes aegypti mosquitoes on probandus hands after being smeared with lotion of basil leaf extract, citronella, clove leaves and betel with a concentration of $40 \%$ in the 1st to 6th hours, citronella leaf extract lotion has the highest protection power $(95 \%)$ while the betel extract lotion had the second protective power $(88.6 \%)$. There is already something that can exceed the protective power of lotion X $(90.3 \%)$, it can be concluded that there is the most effective of the four natural ingredients extract lotions with a concentration of $40 \%$, that is citronella extract lotion.

Protection Power of Extract Lotion Against Aedes aegypti mosquitoes on probandus hands after being smeared with basil extract lotion, citronella leaves, clove leaves and betel with a concentration of $80 \%$ in the 1 st to 6 th hour, citronella leaf extract lotion has the highest protection power $(98.2 \%)$ while the extract lotion which had the second protective power was clove leaves ( $88 \%)$. It can be concluded that the highest protective power of the four lotions of natural extracts with a concentration of $80 \%$ is still in the citronella extract lotion with $98.2 \%$ protection power.

While the extract lotions from natural ingredients of clove, betel and basil leaves are still not able to exceed the protective power of lotion $\mathrm{X}$ $(90.3 \%)$. The most effective citronella leaf extract lotion is proven by the value of its stable protective power even though it has been used for up to 6 hours both with a concentration of $40 \%$ and $80 \%$. The content of the largest citronella compound is citronella up to $40 \%$, has a dehydrating toxicity (Desiccant). This poison is a contact poison that can cause death due to continuous fluid loss. Insects exposed to this poison will die because of lack of fluids. (Agus Kardinan. 2007) b) The Difference of Lotion Extract Protection Power

The test results of the difference in protection against A. aegyptid mosquitoes from the lotion of basil leaf extract, citronella leaves, clove leaves, and betel leaf at a concentration of $20 \%$. Previously, the data normality test showed that the data were normally distributed, this can be seen from the probability value that is greater than 0.05 , it is known that the data variance is not homogeneous with a $\mathrm{p}$ value of 0.021 so that it cannot be continued to the parametric difference test. The alternative test for difference is using kruskall wallis.

The results of the Kruskal Wallis difference test from the mean rank table show that the protective power of extract lotions at a concentration of $20 \%$, the biggest is the protective power of betel leaf (mean rank: 15.67), followed by cironella (mean rank: 14.33). From the test statistics table of the wallis crucal test, it is known that chi-Square: 3.144 and pvalue 0.370 (p-value> 0.05), so it can be concluded that the protective power of extract lotion is not significantly different.

Based on the different test using One Way Anova, it is known that the $p$ value is 0.032 ( $p$ value $<0.05$ ), so it can be concluded that the protection power of extract lotions is significantly different.

Based on the LSD or Bonferroni advanced test, it can be seen that the most different protective power of extract lotions is the protection power of clove leaf extract lotions. There was a significant difference between the protection power of citronella leaf extract lotion and clove leaves (210500) and citronella and basil leaves (112333). positive, meaning that the protective power of the citronella leaf extract lotion is the greatest compared to the other three leaf extracts.

The test results of the difference in protection against A. aegyptid mosquitoes from the lotion extract of basil leaves, citronella leaves, clove leaves, and betel leaf at a concentration of $40 \%$. Previously, the data normality test showed that the data were normally distributed, this can be seen from the probability value that is greater than 0.05 , it is known that the variance of the data is homogeneous with a $p$ value of 0.502 , so that it can be continued to the parametric difference test using one way ANOVA.

The test results of the difference in protective power against $\mathrm{A}$. aegyptid mosquitoes from the lotion of basil leaf extract, citronella leaves, clove leaves, and betel leaf at a concentration of $80 \%$. Previously, the data normality test was carried out and the p-value 
results were obtained in the Shapiro Wilk test for citronella leaf extract lotion, clove leaves, and betel leaf $>0.05$. It can be concluded that the data on the protection power of extract lotions are normally distributed.

From the levene statistical test, it is known that the variance of the data is not homogeneous with a $p$ value of 0.049 so that it cannot be continued to the parametric difference test. The alternative test for difference is using kruskall wallis.

The result of Kruskal Wallis difference test from the mean rank table shows that the protection power of extract lotion at a concentration of $80 \%$, the biggest being the protective power of citronella leaves (mean rank 18.50), followed by cloves (mean rank 12.50). From the table of test statistics wallis crucal test, it is known that the p-value is 0.081 (pvalue> $0.05)$, so it can be concluded that the protection power of extract lotion is not significantly different.

The comparison test results of the protective power against A. aegypti mosquitoes from the lotion extracts of basil leaves, citronella leaves, clove leaves, and betel leaves at $80 \%$ concentration with positive control lotion $\mathrm{X}$

Previously, the data normality test was carried out and the results obtained from the $p$ value of the Shapiro Wilk test for lotion extracts of basil leaves, cloves and betel leaves and positive control for lotion $\mathrm{X}$ were normally distributed.

From the homogeneity test, it is known that the variance of the data is homogeneous with a $p$ value of 0.066 so that it can be continued to the parametric difference test, namely the ANOVA test.

Based on the ANOVA test results, it is known that the $\mathrm{F}$ value is 2.078 with a $\mathrm{p}$ value of 0.114 ( $\mathrm{p}$ value $>0.05$ ) that there is no significant difference in protective power between the 5 repellent groups at a concentration of $80 \%$.

c) Effectiveness of power protection

Based on Graph 4.1, it is known the effectiveness of the protective power against Ae. Aegypti from clove leaf extract, betel leaf extract and citronella extract at the first to sixth hour with a concentration of $20 \%$ it can be concluded that none of the four extract lotions are the most effective.

Based on Graph 4.2, it is known that the effectiveness of protection against the Ae mosquito. Aegypti from clove leaf extract lotion, betel leaf extract lotion and citronella extract lotion at the 1st to 6th hour with a concentration of $40 \%$ it can be concluded that the most effective is citronella extract lotion, as evidenced by the value of its stable protection even though it has used for up to 6 hours. The concentration of citronella extract proved to be effective in repelling Aedes aegypti mosquitoes since the concentration of citronella extract was $10 \%$ and at a concentration of $20 \%$ citronella extract was able to reject 99\%. (Ade Zuhri 2008).

Based on Graph 4.3, it is known that the effectiveness of the protective power against the Ae. Aegypti from clove leaf extract lotion, betel leaf extract and citronella extract at the first to sixth hour with a concentration of $80 \%$, it can be concluded that the most effective is citronella extract, as evidenced by the value of stable protection even though it has been used for up to 6 The greatest protection power during the 6 hours treatment is the protection power of citronella extract with a concentration of $80 \%$ protection power of $86.4 \%$, then the second betel leaf extract with a concentration of $80 \%$ protection power of $81.8 \%$, and the third citronella extract with a concentration of $40 \%$ protection power of $79.7 \%$ (Agus Subagiyo 2017).

d) Protection power of various extract lotions with a concentration of $20 \%$, none of which can exceed the protective power of lotion X, the highest protection power at a concentration of $20 \%$ is betel leaves extract lotion $(81.5 \%)$. Lotion $\mathrm{x}$ has a protective power $(90.3 \%)$

From graph 4.5 above, it can be concluded that lemongrass with a concentration of $40 \%$ has a protective power (average $95 \%$ ) which can exceed the protective power of lotion X. (average 90.3).

From the graph above, it can be concluded that $80 \%$ lemongrass has a protective power $(98.2 \%)$ which can exceed the protective power of lotion $\mathrm{X}$.The most effective lotion is the citronella extract lotion with a concentration of $20 \%(81.1 \%), 40 \%$. (95\%), $80 \%(98.2 \%)$ and it is proven from the value of the protective power which is stable even though it has been used for up to 6 hours.

\section{Conclusions and Suggestions}

Based on the research results it can be concluded that:

a. The average number of mosquitoes that landed after applying the Basil leaf extract lotion was the lowest at a concentration of $80 \%$ (2 mosquitoes)

b. The average number of mosquitoes that land after being smeared with the lowest citronella leaf extract lotion is at a concentration of $80 \%$ ( 1 mosquito)

c. The lowest average number of mosquitoes that landed after applying the clove leaf extract lotion was at a concentration of $80 \%$ (2 mosquitoes) 
d. The average number of mosquitoes that landed after being smeared with betel leaf extract lotion was the lowest at a concentration of $80 \%$ (2 mosquitoes)

e. The highest protection power at a concentration of $80 \%$, basil leaf extract lotion reaches $83.9 \%$, citronella leaf extract lotion reaches $98.2 \%$; clove leaf extract lotion reached $88 \%$. betel leaf extract lotion reached $86 \%$.

f. The difference in the protective power of the lotion extracts of basil leaves, citronella leaves, clove leaves, and betel leaves at a concentration of $20 \%$ and $80 \%$ of the protective power was not significantly

\section{References}

Agus Kardinan, 2006, Tanaman Pengusir Dan Pembasmi Nyamuk, Tangerang : Agromedia Pustaka.

Agus Subagiyo,2017, efektifitas ekstrak berbagai jenis tanaman sebagai repellent nyamuk aedes aegypti

Anonim. 1911. The British Farmaceutical Codex. Diterbitkan oleh Dewan Pharmaceutical Society of Great Britain.

Budi Imansyah, 2008, Ekstrak Serai, Pengusir Nyamuk Alamiah. Bandung: AKL.

Depkes RI, 1999, Indonesia Sehat 2010, Jakarta : Depkes RI.

http://enjcorp.wordpress.com, Membasmi Aedes aegypti Dengan Ekstrak Serai.

http://www.korantempo.com/news/2004/2/29, Informasi Kesehatan Tanaman Pengusir Nyamuk.

Kardinan, A., \& Dhalimi, A. (2010). Potensi Adas (Foeniculum vulgare) sebagai Bahan Aktif Lotion AntiNyamuk Demam Berdarah (Aedes aegypti). Bul.Littro, 21(1), 61-68.

Komisi Pestisida, 1995, Metoda Standar Pengujian Efikasi Pestisida, Departemen Pertanian.

Mitsui. 1997. New Cosmetic Science. NewYork: Elsevier. different, while at a concentration of $40 \%$ it was significantly different.

g. The most effective protection against mosquitoes Ae. aegypti is a citronella extract lotion with a concentration of $80 \%(98.2 \%)$. proven by the value of a stable protective power even though it has been used for up to 6 hours and can exceed the protective power of the lotion brand X $(90.3 \%)$

\section{Suggestion}

It is necessary to develop further research to optimize citronella extract lotion with the orgonolaptic test of color, aroma, stickiness and comfort of its use.

Sastrohamidjojo, H. 2004. Kimia Minyak Atsiri. Gajah Mada University Press.Yogyakarta.

Setyaningsih, Dwi., dkk. 2013. Aplikasi Minyak Sereh Wangi (Citronella Oil) Dan Geraniol Dalam Pembuatan Skin Lotion Penolak Nyamuk. Jurnal Teknik Industri PertanianIPB. Vol. 17(3),97-10

Sri Astuti dan Sukowati, 2002, Masalah Penyakit Tular Vektor, Kebijakan Penelitian dan Pengembangan Vektor di Indonesia, Seminar II Peringatan Hari Nyamuk di BPVRP Salatiga.

Subiyakto Sudarmo, 1991, Pestisida, Yogyakarta : Penerbit Kanisius

Undang-undang Republik Indonesia Nomor 23 Tahun 1997 tentang Pengelolaan Lingkungan Hidup.

World Health Organization / Organisasi Kesehatan Dunia (WHO), Demam Berdarah Dengue: Diagnosis, Pengobatan, Pencegahan dan Pengendalian Edisi 2, Jakarta : Penerbit Buku Kedokteran EGC.

Xue, R.D., Barnard, D.R., \& Ali, A. (2003). Laboratory evaluation of 18 repellent compounds as oviposition deterrents of Aedes albopictus and as larvicides of Aedes aegypti, Anophelesquadrimaculatus, and Culexquinquefasciatus. J Am Mosq ControlAssoc , 19(4), 397-403. 